\title{
Efficiency of second allogeneic HSCT in the children with acute leukemias with relapses after first transplantation
}

\author{
Polina V. Kozhokar ${ }^{1}$, Olesya V. Paina ${ }^{1}$, Anastasia S. Frolova ${ }^{1}$, Zhemal Z. Rakhmanova ${ }^{1}$, Anastasia S. Borovkova ${ }^{1}$, \\ Elena V. Semenova ${ }^{1}$, Anna A. Osipova ${ }^{1}$, Kirill A. Ekushov ${ }^{1}$, Olga A. Slesarchuk ${ }^{1}$, Varvara N. Ovechkina ${ }^{1}$, \\ Elena V. Babenko ${ }^{1}$, Alina A. Vitrishchak ${ }^{1}$, Boris I. Smirnov ${ }^{2}$, Ludmila S. Zubarovskaya ${ }^{1}$, Boris V. Afanasyev ${ }^{1}$ \\ ${ }^{1}$ Raisa Gorbacheva Memorial Research Institute of Pediatric Oncology, Hematology and Transplantation, Pavlov University, \\ St. Petersburg, Russia \\ ${ }^{2}$ Saint Petersburg State Electrotechnical University, St. Petersburg, Russia
}

\section{Dr. Polina V. Kozhokar, Clinical Hematologist, Bone Marrow Transplantation Department for Children, Raisa Gorbacheva Memorial Research Institute of Pediatric Oncology, Hema- tology and Transplantation; Pavlov University, St. Petersburg, Russia}

Phone: +7 (903) 0997319

E-mail: kozhokar.polina@gmail.com

Citation: Kozhokar PV, Paina OV, Frolova AS et al. Efficiency of second allogeneic HSCT in the children with acute leukemias with relapses after first transplantation. Cell Ther Transplant 2019; 8(4): 33-40.

\section{Summary}

Allogeneic hematopoietic stem cell transplantation (allo-HSCT) is effective treatment in high risk hematological malignancies. Nevertheless, the relapse rates after allo-HSCT range from $10 \%$ to $70 \%$. There are no optimal strategy of the relapse therapy after allo-HSCT. Possible therapeutic options include re-induction chemotherapy, immunoadoptive therapy (DLI), target drugs, immunotherapy (CAR-T) and second allo-HSCT. The presented study is a retrospective single-institution experience of second allo-HSCT in the patients (pts) with acute leukemia relapses or graft failure in high-risk cases. The aim of our study was to analyze the outcomes after second allo-HSCT in 50 children with hematological malignancies, i.e., ALL ( $n=24)$, AML ( $n=15), \operatorname{MPDs} / \operatorname{MDS}(n=11)$.

\section{Results}

Forty-four patients achieved engraftment, with median neutrophil engraftment time of 21 days (12 to 41 ). Remission was achieved in 44 pts (88\%). Median follow-up period was 3 years 7 months. Overall survival (OS), according to Kaplan-Meier method, was $48 \%$ in the whole group. Relapse-free survival (RFS) was $60 \%$. The fiveyear OS in ALL group was 46.2\%; in AML group, 53.3\%; in MPDs/MDS, $44.4 \%$. Causes of death were as follows: relapse/progression in 65\% $(n=17)$, transplant-related mortality (TRM), in $18 \%(\mathrm{n}=9$; $95 \% \mathrm{CI}, 8.8 \%-29.8 \%)$; cumulative relapse rate was $34 \%$ (95\% CI, $21.6 \%-48 \%$ ).

\section{Conclusion}

Second allo-HSCT is an effective treatment option in cases of relapse after $1^{\text {st }}$ allo-HSCT. The patients that achieved remission or even blast cytoreduction prior to $2^{\text {nd }}$ allo-HSCT had better outcome. Clinical manifestations of acute and chronic GVHD can significantly improve the OS. Results of $2^{\text {nd }}$ allo-HSCT were comparable when using RIC or MAC conditioning regimens. Posttransplant therapy is required to improve results after $2^{\text {nd }}$ HSCT.

\section{Keywords}

Leukemia relapse, second allogeneic HSCT, posttransplant therapy, children. 


\section{Introduction}

Allogeneic transplantation of hematopoietic stem cells (allo-HSCT) is among superior advances in treatment of children with hematological and inherited disorders [1]. Improvement of treatment protocols based on the balanced intensification of chemotherapy (ChT) provides an increase in long-term survival of the children with acute myeloid leukemia (AML) to 70\%, and acute lymphoblastic leukemia (ALL) in $90 \%$ of the cases. Chemotherapy followed by allogeneic HSCT is one of the most effective treatment methods remaining an integral part of programmed therapy for highrisk pediatric AML and ALL [2]. Relapse of acute leukemia remains a main indication for allo-HSCT, due to sufficient worsening of prognosis [17].

Along with high-risk acute leukemia in children, allo-HSCT is the only method of treatment in myelodysplastic syndrome (MDS), including juvenile myelo-monocytic leukemia (JMML) (14). Chronic myeloid leukemia (CML) deserves special indications, i.e., in cases of lost therapeutic response, intolerance to tirosine kinase inhibitors (TKI), or mutations associated with TKI resistance permit us to consider allo-HSCT a therapeutic option, due to high efficiency and individual indication strategy.

Allo-HSCT performance is accompanied by some serious complications associated with conditioning regimens, non-engraftment or graft hypofunction, and especially with relapses. Post-transplant relapse remains the most serious issue, being the main cause of mortality in these patients [1, $2,9,12]$. Frequency of leukemia relapses after allo-HSCT is from 10 to $70 \%[1,3,4]$. Prognosis for relapsing patients posttransplant is dismal, and the patients are planned for salvage therapy requiring personalized treatment approach [2]. Among possible therapies applicable after allo-HSCT, one may consider re-transplantation, the use of target and immunotherapy drugs. However, their efficiency of these options has not proven in randomized trials. Nevertheless, the reported experience of different centers is of sufficient interest for taking strategic clinical decisions. The range of problems associated with re-transplantation due to relapse is as follows - to date, the optimal timing for $2^{\text {nd }}$ HSCT are not yet determined; there is no clear opinion on the graft source (bone marrow or peripheral stem cells), and donor characteristics (HLA matching, gender, age), as well as conditioning regimens, GVHD prophylaxis, subsequent therapies.

A retrospective analysis was performed at the R. M. Gorbacheva Memorial Research Institute for Children Oncology, Hematology and Transplantation concerning 50 pediatric patients with different malignant hematological diseases who were subjected to repeated allo-HSCT due to relapse or progression, primary or secondary non-engraftment. The aim of our study was to evaluate efficiency of $2^{\text {nd }}$ allo-HSCT in the patients with acute leukemias, MDS, JMML, and CML in cases of evolving clinical relapse, or associated complications occurring after the $1^{\text {st }}$ allo-HSCT.

\section{Materials and methods}

The study included 50 children with a median age of 18 years (1 to 18 y.o.) subjected to $2^{\text {nd }}$ allo-HSCT at our BMT clinic from 2007 to 2018. Their primary diagnoses were as follows: ALL, 24 patients; AML, 15 cases; mixed-phenotype AML, 2 patients; JMML, 6 patients; CML, 1 patient. Relapse of the primary disease was the most common indication for $2^{\text {nd }}$ allo-HSCT was diagnosed in 36 cases (72\%). Other indications for $2^{\text {nd }}$ HSCT were as follows: primary non-engraftment in 11 patients (22\%); secondary non-engraftment in 2 patients $(4 \%)$; graft hypofunction in one case $(2 \%)$ in presence of resistant/refractory clinical course. The disease characteristics and parameters of the $1^{\text {st }}$ HSCT are presented in Table 1.

\section{Table 1. Clinical characteristics of pediatric patients considered for $2^{\text {nd }}$ allo-HSCT}

\begin{tabular}{|l|l|}
\hline Patients & $\mathrm{n}=50$ \\
\hline Median age, years & 5 (1 to 18) \\
\hline Gender, M/F & $27 / 23$ \\
\hline Disease status & \\
I remission & 16 \\
II, III remission & 18 \\
Active disease & 16 \\
\hline Donor: HLA matching & \\
Related, matched & 20 \\
Non-related, matched & 14 \\
Haploidentical & 14 \\
Syngeneic/autologous & $1 / 1$ \\
\hline Conditioning & \\
Myeloablative regimens (MAC): & \\
Based on Busulfan, Treosulfan: & 34 \\
Bul6Cy, Bul2Flu, GIAC, TreoFlu & \\
\hline Reduced-intensity conditioning (RIC): & 16 \\
Melphalan + Fludarabin & \\
\hline
\end{tabular}

Abbreviations: BU, Busulfan; Treo, Treosulfan; Flu, Fludarabine; Cy, Cyclophosphamide; GIAC, Bu, Ara-C, CCNU, Cy; MAC, myeloablative conditioning, RIC, reduced-intensity conditioning.

For $40 \%$ of the patients ( $n=20)$, unrelated HLA-matched donors were chosen for allo-HSCT; matched related donor was used in 15 cases (30\%); haploidentical graft was used in 14 cases (28\%); autologous HSCT was carried out in 1 patient (2\%). At the time of $1^{\text {st }}$ HSCT, myeloablative busulfan-containing regimen (MAC) was applied in 34 patients (68\%). Dependent on the stage of disease, 16 patients (32\%) achieved $1^{\text {st }}$ complete hematological remission (CR); $2^{\text {nd }}$ or $3^{\text {rd }} \mathrm{CR}$ was registered in 18 cases (36\%). Sixteen patients (32\%) were in resistant relapse state, or showed primary resistance.

Median duration of remission after the $1^{\text {st }}$ allo-HSCT was 148 days (31 to 1084 days). Donor lymphocyte infusions (DLI) were performed in 20 patients after $1^{\text {st }}$ allo-HSCT, for relapse prophylaxis. Of them, 17 children (85\%) received the therapy due to minimal residual disease (MRD) or clinical relapse, and 3 patients (15\%), due to graft hypofunction. The DLI proved to be ineffective in all these patients, thus being indicative for $2^{\text {nd }}$ allo-HSCT. 
The patients with progression or relapse after $1^{\text {st }}$ HSCT $(n=38)$, have received cytoreductive therapy before $2^{\text {nd }}$ alloHSCT by the following schedules:

- chemotherapy (ChT) in 24 patients using FLAG protocol, or ALL-REZ BFM 2002, and AML-BFM 2004 chemotherapy blocks;

- targeted drugs (hypomethylating agents or monoclonal antibodies), in 7 patients;

- combined application of ChT and targeted drugs (hypomethylating or monoclonal antibodies) in 7 cases.

In 10 patients of 38 who underwent ChT or targeted treatment, a remission of the disease was achieved; in 12 cases, cytoreduction was observed (marrow blast count reduction to $20 \%$ ). In 16 patients, stabilization or progression of the disease was registered.

Ten patients with aplasia of hematopoiesis due to primary non-engraftment, 2 patients with secondary rejection, and 1 patient with severe graft hypofunction did not receive additional therapy. Clinical characteristics of the patients subjected to $2^{\text {nd }}$ allo-HSCT are shown in Table 2.

Table 2. Clinical characteristics of the patients who underwent $2^{\text {nd }} \mathrm{HSCT}$

\begin{tabular}{|l|l|}
\hline Patients & $\mathbf{n}=50$ \\
\hline Median age, years & 7 (1 to 20) \\
\hline Gender, M/F & $27 / 23$ \\
\hline $\begin{array}{l}\text { Donor: HLA matching } \\
\text { Non-related, matched } \\
\text { Related, matched } \\
\text { Haploidentical }\end{array}$ & 4 \\
\hline $\begin{array}{l}\text { Disease status } \\
\text { Remission } \\
\text { Cytoreduction to <20\% blasts } \\
\text { in bone marrow } \\
\text { Progression }\end{array}$ & 2 \\
\hline $\begin{array}{l}\text { Conditioning regimen } \\
\text { Myeloablative protocols: }\end{array}$ & 19 \\
Busulfan-based (BuFlu, GIAC) & 14 \\
\hline $\begin{array}{l}\text { Reduced-intensity protocols: } \\
\text { based on Melphalan, Treosulfan })\end{array}$ & 17 \\
\hline $\begin{array}{l}\text { CD34+ cells/kg body mass } \\
\text { Hematopoietic stem cell (HSC) } \\
\text { source: } \\
\text { Non-manipulated bone marrow } \\
\text { Non-manipulated PBSC } \\
\text { Combined bone marrow+PBSC }\end{array}$ & 40 \\
\hline
\end{tabular}

Abbreviations: BU, Busulfan; Treo, Treosulfan; Flu, Fludarabine; Cy, Cyclophosphamide; GIAC: Bu, Ara-C, CCNU, Cy; MAC, myeloablative conditioning, RIC, reduced-intensity conditioning; HSCs, hematopoietic stem cells; PBSC, peripheral blood stem cells

The median time-lag between $1^{\text {st }}$ and $2^{\text {nd }}$ HSCT was 7.5 months. In majority of patients $(n=41)$, the donors were changed to haploidentical HSCs donor. In 9 recipients,
allo-HSCT was performed from the same donors, i.e., haploidentical transplants in 3 cases; unrelated grafts in 4 patients, and related matched donors were used in 2 cases. For $2^{\text {nd }}$ allo-HSCT, the reduced-intensity conditioning regimens (RIC) were chosen for 40 patients, due to heavy pre-treatment and severe condition of the patients. Myeloablative conditioning was performed in 10 cases, because of high blast cell counts in bone marrow. Combined prophylaxis of acute graft-versus-host disease (GvHD) after $2^{\text {nd }}$ alloHSCT was based on the following immune suppression therapy, i.e., tacrolimus-based prophylaxis was administered to 38 patients; mTOR inhibitors were used in 31 cases; cyclosporine-A-based was applied in 7 patients. In 31 cases, GvHD prophylaxis was performed with cyclophosphamide (50 $\mathrm{mg} / \mathrm{kg}$ ) on D+3 and D+4 posttransplant. Antithymocyte globulin (ATG) was used for GVHD prophylaxis in 11 cases. Monotherapy with calcineurin inhibitors was applied in 7 children.

The Kaplan-Meier estimates were used to assess probability of OS (overall survival) and RFS (relapse-free survival). OS was defined as number of months from the date of $2^{\text {nd }}$ allo-HSCT to the date of death. RFS defined as number of months from the date of $2^{\text {nd }}$ allo-HSCT to the date of first documented relapse or progression. Cumulative incidence was used to estimate the probability of transplant-related mortality (TRM) and relapse. For TRM, the relapse was considered a competing event. These estimates are provided with 95\% confidence intervals (CI). We didn't perform any multivariate analysis, because of relatively small number of patients.

\section{Results}

Clinical engraftment after $2^{\text {nd }}$ HSCT was registered in 44 patients $(88 \%$ of total), with a median of neutrophil recovery of $>500 / \mathrm{mcL}$ on $\mathrm{D}+21$ ( 12 to 41 ), and documented clinical hematological remission. Primary non-engraftment was registered in 6 patients, including 4 cases with progression of the disease. The median observation term was 3 years 7 months ( 9 months to 10 years). Overall survival (OS) rate in the total group was $48 \%$ (Fig. 1), with relapse-free survival (RFS) of $60 \%$ (Fig. 3). OS among ALL patients was $46.2 \%$; among the children with AML, 53.3\%; for the group with myeloproliferative disorders (MDS, CML, JMML), 44.4\%, as seen from Fig. 1.

OS among the patients with remission or cytoreduction achieved before $2^{\text {nd }}$ allo-HSCT proved to be, respectively, $73.6 \%$ и $50 \%$. Meanwhile, OS values in the patients who did not respond to the therapy, on in absence of remission (active disease) comprised only 17.6\% $(\mathrm{p}=0.006)$, as shown in Fig. 2.

We could not demonstrate any significant difference in OS between the cases with remission of $<5$ months, and $>5$ months after $1^{\text {st }}$ HSCT (respectively, $41.2 \%$ and $42.9 \%$, $\mathrm{p}=0.7$ ), based on median duration of the remission. Similarly, change of donor at the $2^{\text {nd }}$ HSCT did not result into significant OS changes ( $50 \%$ versus $47 \%, \mathrm{p}=0.4$ ). Moreover, no statistically significant difference was obtained for the groups who received RIC or MAC conditioning (47\% versus $50 \%, \mathrm{p}=0.6)$. 

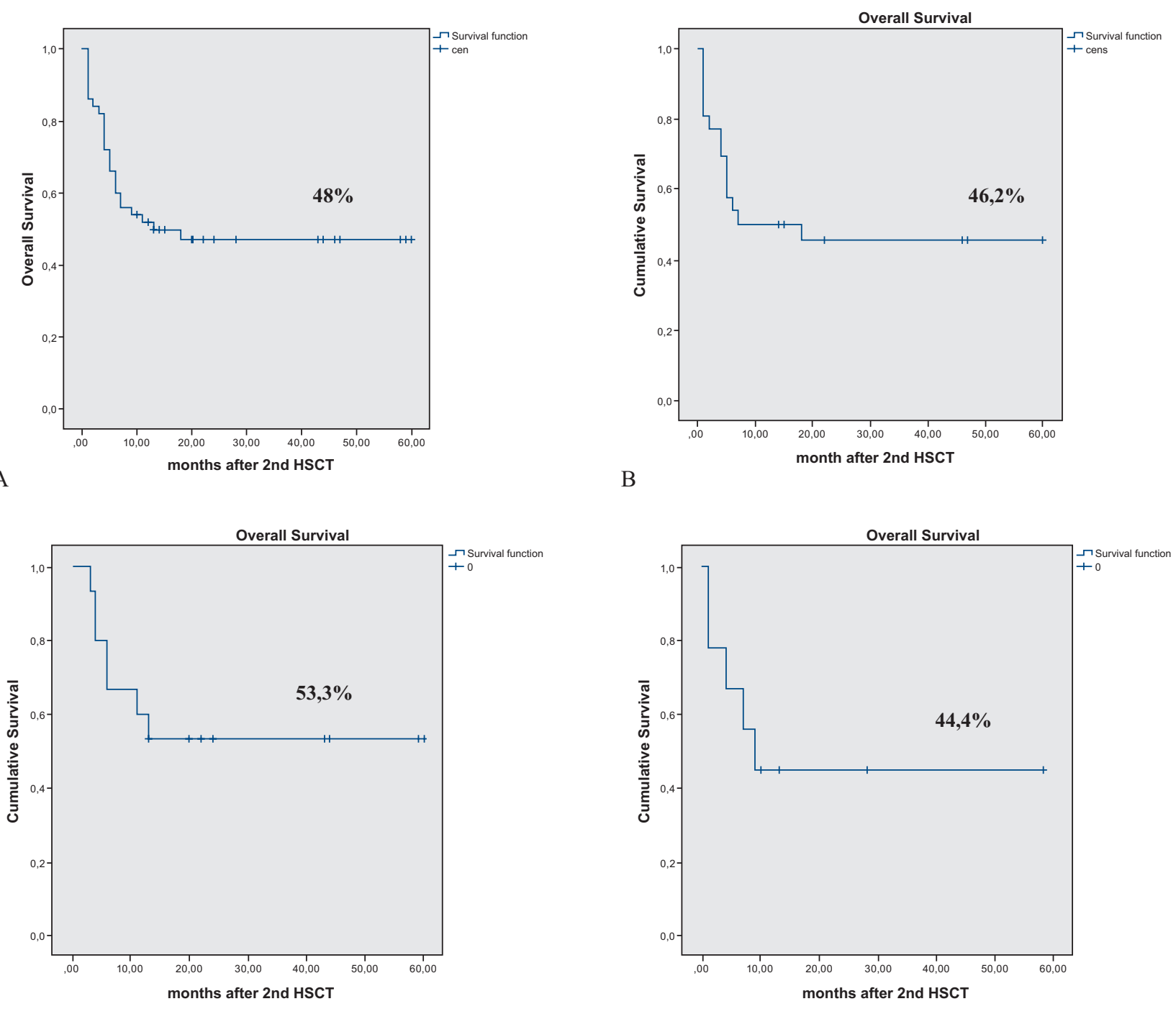

$\mathrm{C}$

D

Figure 1. Five-year OS after $2^{\text {nd }}$ allo-HSCT in the entire cohort (A); in patients with ALL (B); in patients with AML (C); in MPD cases (D) after $2^{\text {nd }}$ allo-HSCT

Abscissa, months after allo-HSCT, ordinate, cumulative survival.

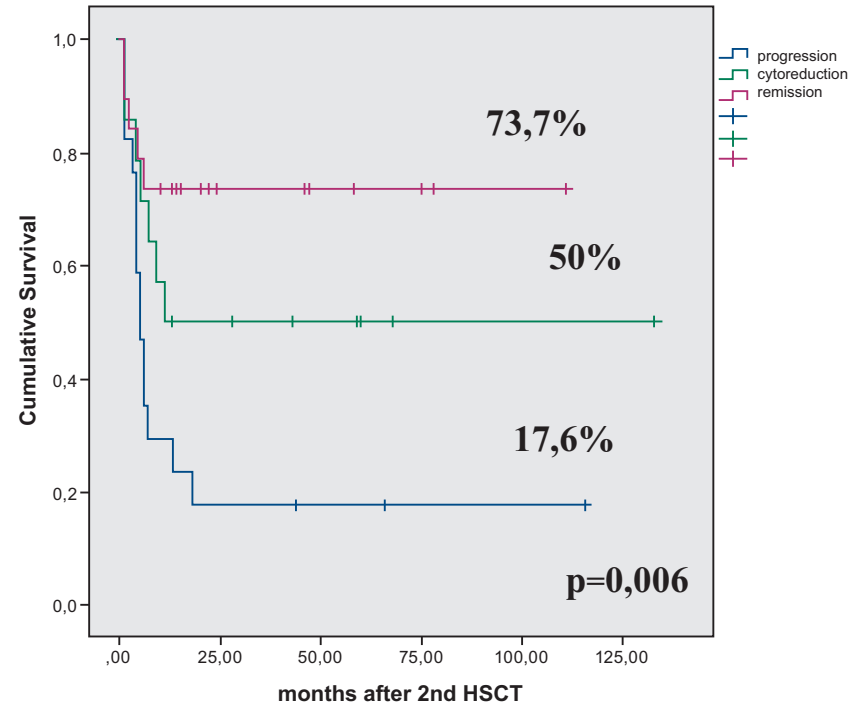

Figure 2. Overall survival in the patients with different status prior to $2^{\text {nd }}$ allo-HSCT (red graph, remission; green, cytoreduction; blue curve, no response)

Abscissa, terms after $2^{\text {nd }}$ HSCT, months; ordinate cumulative survival.

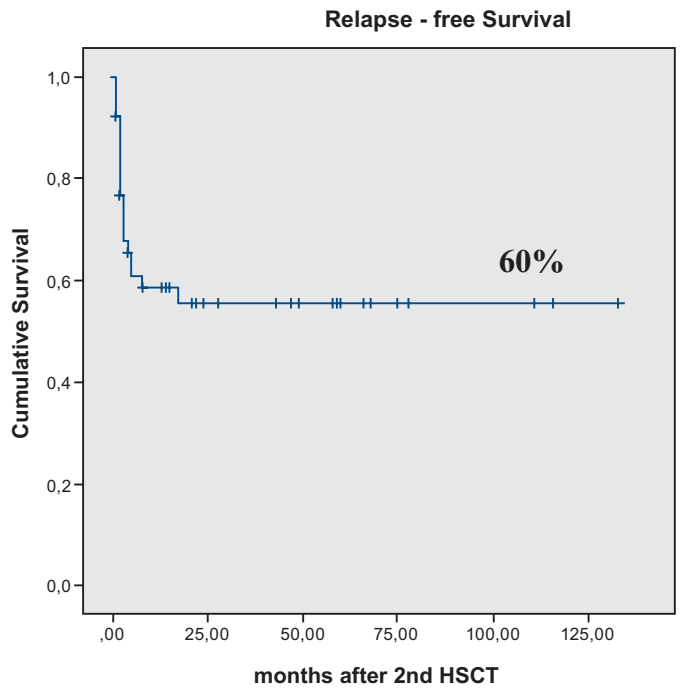

Figure 3. Relapse-free survival in the entire group of patients after $2^{\text {nd }}$ allo-HSCT

Abscissa, terms after $2^{\text {nd }}$ HSCT, months; ordinate cumulative survival. 
The study also concerned possible effects of acute or chronic GvHD upon OS levels. The 5-year OS in the patients (remission - 18 pts, cytoreduction - 12 pts, progression - 11 pts) who developed acute GVHD grade II-III was $63.6 \%$ $(n=33)$, as compared to $9.1 \%(n=11)$ among GvHD-free cases $(\mathrm{p}=0.001)$. Meanwhile, the 5-year OS rate among patients with mild or moderate chronic GvHD reached $72.4 \%(n=29)$ when compared to the cases without chronic GvHD 14.3\%, $(\mathrm{n}=7), \mathrm{p}<0.0001)$.

From patients with high risk of relapse after $2^{\text {nd }}$ allo-HSCT, 9 patients without acute or chronic GvHD were subjected to immunoadoptive therapy, i.e., infusion of donor lymphocytes (DLI), aiming to prevent potential relapse. Maintenance therapy was performed in 13 patients using 6-MP (mercaptopurine), hypomethylating agents (HMa) (5-azacytidine, dacogen), tyrosine kinase inhibitors (TKI). In summary, for the group of patients $(n=13)$ who did not receive any prophylaxis (DLI) or supporting therapy (6-MP, HMa or TKI) after $2^{\text {nd }}$ all-HSCT, due to acute or chronic GvHD OS $84.6 \%,(\mathrm{p}=0.089)$.

Overall survival was $55.6 \%$ among the patients treated with DLI only. In the patients on maintenance therapy, the OS values proved to be $46.2 \%$. In 9 cases of molecular recurrence (MRD, molecular or cytogenetic relapse) combined therapy was performed, i.e., chemotherapy, HMa (5-azacytidine, dacogen) and DLI, with OS of $22.2 \%(\mathrm{p}=0.089)$.

We have analyzed the frequency of complications during early posttransplant period $(\mathrm{D}+100)$. The following toxic conditions were observed: severe mucositis (grade 3-4) was documented in $54 \%$ of cases $(n=26)$; thrombotic microangiopathy, $22 \%(\mathrm{n}=11)$; veno-occlusive disease, $16 \%(\mathrm{n}=8)$; neurotoxicity, $16 \%(\mathrm{n}=8)$. Among infectious complications, we observed cytomegalovirus reactivation (52\%, $\mathrm{n}=26)$; SIRS syndrome, including sepsis, $44 \%(n=22)$; invasive mycoses, $18 \%(n=9)$.

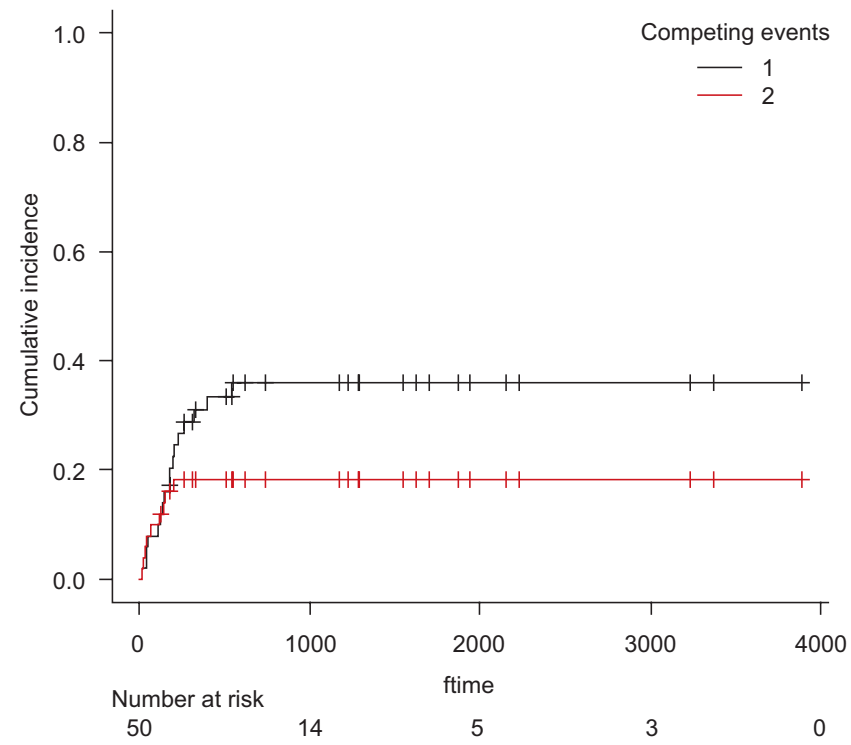

Figure 4. Effects of 2 competing events upon general mortality after $2^{\text {nd }} \mathrm{HSCT}$, i.e., (1) cumulative relapse rate (34\%; 95\%Cl, 21.6\%-48\%), and (2) TRM rate (18\%; 95\%Cl, 8.8-29.8\%)
Relapse or progression of disease remained the main cause of mortality after $2^{\text {nd }}$ allo-HSCT $(65 \%, n=17)$. The median time of the relapse development in these patients comprises 58 days.

Transplant-related mortality in this group was $18 \%$, (95\%CI, 8.8-29.8\%) and the relapse rate (a competing event) was 34\% (95\%CI, $21.6 \%$ to $48 \%$ ), as shown in Fig. 4.

\section{Discussion}

Hematopoietic stem cell transplantation is the only possible treatment method in the most high-risk malignancies in children (AML, ALL etc.) [2]. Despite significant advances in the area, the posttransplant relapses remain the quite serious and common issue, being the main cause of lethal outcomes posttransplant $[1,2,9,12,15]$. The relapse frequency in this cohort may vary from 10 to $70 \%[3,4,15]$. Clinical prognosis for post-HSCT relapsing patients remains extremely unfavorable, and these patients were intended for the salvage therapy [2]. So far, there are no clear clinical recommendations for treatment of such patients, and the issue of therapeutic options still remains open for this group [10,15].

A significant therapeutic effect in allogeneic HSCT is achieved due to immune-mediated reactions, e.g., transplant versus leukemia effect, the main factor able to overcome the resistance of malignant cells $[4,10]$. However, subsequent administration of mono- or combined therapy is the most common strategy for treatment of the posttransplant relapses, i.e., reinduction polychemotherapy, immunoadoptive cell therapy (donor lymphocyte infusion), usage of targeted drugs including monoclonal antibodies (MAb) [12]. Intensive chemotherapy results into the disease stabilization with remission achieved in 40 to $60 \%$ [4], however, without long-lasting effect in most cases, with 2 -year OS of $<10 \%$ [4].

Therapeutic potential of bispecific anti-CD19 monoclonal antibodies in the patients with ALL relapse was evaluated in a multicenter study of the patients who relapsed after HSCT, with a median observation term of 7.5 months. The one-year overall survival in these patients was $25 \%$ following treatment with blinatumomab [7].

According to the study by Markova et al. [11] that included 41 children with posttransplant relapse of ALL, the response to blinatumomab was observed in 24 patients (59\%); the two-year OS comprised 37\%, 2-year relapse-free survival rate was $71 \%$, with a median observation terms of 222 days (25 to 730 days).

Donor lymphocyte infusion is an effective treatment approach in such conditions [12]. On the ground of a retrospective study which included 171 cases, Shmid et al. have shown efficiency of donor lymphocytes when treating posttransplant relapses in AML patients. The 2-year OS among the patients achieving remission after DLI was $56 \%$, as compared with OS of $21 \%$ in the patients that did not reach the remission state ( $>35 \%$ blasts in bone marrow). Meanwhile, the 2 -year OS remained at $9 \%$ for the patients who did not receive DLI [6]. 
EBMT Acute Leukemia Working Party (M. A. Kharfan-Dabaja et al, 2018) has published a retrospective study in order to compare efficiency of repeated allo-HSCT and DLI, including 418 adult patients with AML relapse after $1^{\text {st }}$ allo-HSCT. Repeated allo-HSCT was performed in 137 patients, and DLI, in 281 patients. Two-year survival following repeated allo-HSCT proved to be $26 \%$, 5-year OS comprised $19 \%$. Two-year OS among the DLI-treated patients was 25\%, and 5-year OS, 15\% [16]. In our study, the 5-year OS was $48 \%$ after repeated HSCT in general group.

Similarly, several larger studies have shown that repeated HSCT is a probable therapeutic approach [2]. In 2015, Ruutu et al. have summarized the results of 2632 repeated allo-HSCTs. Their results showed the 1 -year OS rates of $40 \%$, 5 -year OS of 20\% [5]. Another study from USA (Swati Naik et al., 2015) demonstrated results of repeated allo-HSCT in 43 children with relapses of different oncohematological disorders, with overall survival at 1, 5 and 10 years of, respectively, 48\%, 24\%, and 20\% [3].

The results of multicenter retrospective study (EBMTPDWP) were reported in 2018 [8]. Repeated allo-HSCT was performed in 373 cases; the 2- and 5-year OS values were $38 \%$ and $29 \%$, respectively. The relapse-free survival was $30 \%$ at 2 years, and $30 \%$ at 5 years of observation. The median observation time in ALL group was 36.4 months, being 50.2 months for AML patients [8].

Despite current achievements in the posttransplant relapse treatment following allo-HSCT, using repeated allo-HSCT, the optimal timing of its performance is not yet determined, as well as preferable HSC source, change of donor (his/her gender and age), conditioning regimen, GVHD prophylaxis, posttransplant treatment, thus requiring additional multicenter studies, e.g. under participation of European teams active in oncohematology [18].

\section{Conclusion}

1. We have performed retrospective study concerning 50 pediatric patients with different blood malignancies that were subjected to repeated allogeneic HSCT due to different reasons, i.e. relapse/progression, primary or secondary non-engraftment.

2. According to our results, the repeated allo-HSCT in this cohort proved to be an effective treatment approach to the therapy of relapses in pediatric malignancies following failure of first allo-HSCT. The $2^{\text {nd }}$ allo-HSCT may be effectively performed in stable somatic status, without active infections and toxic complications, upon development of remission or when achieving response to cytoreductive therapy before conditioning.

3. The option of repeated HSCT depends on clinical situation and presence of toxic complications in distinct cases. However, taking into account previous severe treatment, one should prefer reduced-intensity or reduced-toxicity conditioning regimens, despite absence of statistical difference between results from MAC and RIC cases. There is no difference upon donor change and allo-HSCT type, however, haploidentical donor seems to be preferred in this setting, due to availability, motivation and sooner performance of this HSCT mode.
4. With respect to soon development of relapses after repeated allo-HSCT (a median of 58 days), a decision on withdrawal of immune suppressive therapy and commencing posttransplant immunoadoptive treatment should be taken within $\mathrm{D}+30$ to $\mathrm{D}+60$ in absence of clinically significant GvHD. Administration of other therapies (DLI, hypomethylating and targeted drugs) causes a sufficient improvement of OS rates in the patients following repeated SC.

5. With development of novel monoclonal antibodies, as well as future CAR-T cell technologies, we need further studies of these therapeutic options in the posttransplant period for this cohort of patients.

\section{Conflict of interest}

Non declared.

\section{References}

1. Afanasyev B, Zubarovskaya L, Moiseev I. Allogeneic hematopoietic stem cell transplantation in children: now, problems and prospects. Russian Journal of Pediatric Hematology and Oncology. 2015;2(2):28-42 (In Russian).

2. Arellano M, Langston A,Winton E, Flowers C, Walle E. Treatment of relapsed acute leukemia after allogeneic transplantation: a single center experience. Biol Blood Marrow Transplant. 2007; 13:116-123.

3. Naik S. Martinez C, Leung K, Sasa G, Nguyen N. Outcomes after second hematopoietic stem cell transplantations in pediatric patients with relapsed hematological malignancies. Biol Blood Marrow Transplant. 2015; 21:1266-1272.

4. Shaw B, Russell N. Treatment options for the management of acute leukemia relapsing following an allogeneic transplant. Bone Marrow Transplantation. 2008; 41: 495-503.

5. Ruutu T, Wreede L, Biezen A, Brand R, Mohty M, Dreger P, Duarte R, Peters C, Garderet L, Schönland S, Gratwohl A, Niederwieser D, Witte T, Kröger N. for the EBMT. Second allogeneic transplantation for relapse of malignant disease: retrospective analysis of outcome and predictive factors by the EBMT. Bone Marrow Transplantation. 2015;50(12):15421550 .

6. Schmid C, Labopin M, Nagler A, Bornhäuser M, Finke J, Fassas A, Volin L, Gürman G, Maertens J, Bordigoni P, Holler E, Ehninger G, Polge E, Gorin N-C, Kolb H-J. Donor lymphocyte infusion in the treatment of first hematological relapse after allogeneic stem-cell Transplantation in Adults With Acute Myeloid Leukemia: A Retrospective Risk Factors analysis and comparison with other strategies by the EBMT Acute Leukemia Working Party. J Clin Oncol. 2007; 25:49384945.

7. Gore L, Locatelli F, Zugmaier G, Handgretinger R, O’Brien M, Bader P, Bhojwani D, Schlegel P, Tuglus C, Stackelberg A. Survival after blinatumomab treatment in pediatric patients with relapsed/refractory B-cell precursor acute lymphoblastic leukemia. Blood Cancer J.2018 8(9):80. doi: 10.1038/s41408-018-0117-0. 
8. Yaniv I, Krauss A, Beohou E, Dalissier A, Corbacioglu S, Zecca M, Afanasyev B, Berger M, Diaz M, Kalwak K, Sedlacek P, Varotto S, Peters C, Bader P. Second hematopoietic stem cell transplantation for post-transplant relapsed acute leukemia in children: a retrospective EBMT-PDWP study. Biol Blood Marrow Transplant. 2018;24(8):1629-1642.

9. Duncan C, Majhail N, Zhiwei R, Cahn WJY. Long-term survival and late effects among one-year survivors of second allogeneic hematopoietic cell transplantation for relapsed acute leukemia and myelodysplastic syndromes. Biol Blood Marrow Transplant. 2015; 21:151-158.

10. Blau I, Basara N, Bischoff M, Günzelmann S, Römer E, Kirsten D, Schmetzer B, M Kiehl M, Fauser A. Second allogeneic hematopoietic stem cell transplantation as treatment for leukemia relapsing following a first transplant. Bone Marrow Transplantation. 2000; 25(1): 41-45.

11. Markova I, Zubarovskaya L, Paina O, Bondarenko S, Kozhokar P, Frolova A, Rakhmanova Zh, Galas M, Ekushov K, Babenko E, Gindina T, Barkhatov I, Semenova E, Moiseev I. Assesment of blinatumomab efficacy and safety in treatment of relapses and refractory forms of B-lineage acute lymphoblastic leukemia in children. Pediatria. 2019; 98(4):158-164 (In Russian).

12. Semenova E, Stancheva N, Zubarovskaya N, Babenko E, Slesarchuk O, Estrina M, Zubarovskaya L, Afanasyev B. Post-transplant relapses of acute leukemia in children and adolescents. Bone Marrow Transplantation. 2010; 45 (Suppl 2):94.

13. Semenova E, Stancheva N, Alyanskiy A, Tretyakova M, Razumova S, Borovkova A, Babenko E, Bondarenko S, Shiryaev S, Bykova T, Paina O, Zubarovskaya L, Kozlov A, Afanasyev B. Results of second allogeneic stem cell transplantation for children and adolescents with acute leukaemia. Bone Marrow Transplantation. 2011; 46(Suppl.1): 273.

14. Sakashita K, Matsuda K, Koike K. Diagnosis and treatment of juvenile myelomonocytic leukemia. Pediatrics Int. 2016; 58, 681-690.

15. Bosi A Laszlo D, Labopin M, Reffeirs J, Michallet M, Gluckman E, Alessandrino PE, Locatelli F, Vernant JP, Sierra J, Jouet JP, Frassoni F. Acute Leukemia Working Party of the European Blood and Marrow Transplant Group. Second allogeneic bone marrow transplantation in acute leukemia: results of a survey by the European Cooperative Group for Blood and Marrow Transplantation. J Clin Oncol. 2001; 19(16): 3675-3684.

16. Kharfan-Dabaja AM, Labopin M, Polge E, Nishihori T, Bazarbachi A, Finke J, Stadler M, Ehninger G, Lioure B, Schaap N, Afanasyev B, Yeshurun M, Isaksson C, Maertens J, Chalandon Y, Schmid C, Nagler A, Mohty M. Association of second allogeneic hematopoietic cell transplant vs donor lymphocyte infusion with overall survival in patients with acute myeloid leukemia relapse. JAMA Oncol. 2018; 4(9):1245-1253.
17. Schrappe M, Hunger SP, Pui CH, Saha V. Outcomes after induction failure in childhood acute lymphoblastic leukemia. New Engl J Med. 2012; 366(15):1371-1381.

18. Fedorova LV, Lepik KV, Popova MO, VlasovaYY, Kudyasheva OV, Rogacheva YA, Lepik EE, Porunova VV, Osipova AA, Zalyalov YR, Darskaya EI, Markova IV. Highlights of the 24th European Hematology Association Congress, Amsterdam 2019. Cell Ther Transplant 2019; 8(2): 82-90. 


\title{
| Эффективность повторной аллогенной ТГСК у детей с острыми лейкозами при рецидиве после первой трансплантации
}

\author{
Полина В. Кожокарь ${ }^{1}$, Олеся В. Паина ${ }^{1}$, Анастасия С. Фролова ${ }^{1}$, Джемал 3 . Рахманова ${ }^{1}$, Анастасия С. Боровкова ${ }^{1}$, \\ Елена В. Семенова ${ }^{1}$, Анна А. Осипова ${ }^{1}$, Кирилл А. Екушов ${ }^{1}$, Ольга А. Слесарчук ${ }^{1}$, Варвара Н. Овечкина ${ }^{1}$, \\ Елена В. Бабенко ${ }^{1}$, Алина А. Витрищак ${ }^{1}$, Борис И. Смирнов ${ }^{2}$, Людмила С. Зубаровская ${ }^{1}$, Борис В. Афанасьев ${ }^{1}$ \\ ${ }^{1}$ НИИ детской онкологии, гематологии и трансплантологии им. Р. М. Горбачевой, Первый Санкт-Петербургский \\ государственный медицинский университет им. И. П. Павлова, Санкт-Петербург, Россия \\ ${ }^{2}$ Санкт-Петербургский государственный электротехнический университет, Санкт-Петербург, Россия
}

\section{Резюме}

Аллогенная трансплантация гемопоэтических стволовых клеток (алло-ТГСК) является стандартом терапии в группе высокого риска онкогематологических заболеваний. Несмотря на это, уровень рецидивов варьирует от 10 до 70\%. До сих пор отсутствует оптимальный подход к терапии рецидива после алло-ТГСК. Возможные терапевтические опции включают в себя реиндукцию, иммуноадоптивную терапию, таргетную терапию, иммунотерапию (CAR T-клеточную терапию), повторную трансплантацию. В данной публикации представлено ретроспективное исследование пациентов с рефрактерным течением онкогематологических заболеваний, а также отторжением трансплантата в группе высокого риска, в связи с чем выполнялась повторная алло-ТГСК. Целью нашей работы был анализ результатов повторной алло-ТГСК у 50 детей с различными онкогематологическими заболеваниями: ОЛЛ - 24, ОМЛ - 15, МДС и ХМПЗ - 11 пациентов. Общая выживаемость (ОВ) по методу Каплан-Майер во всей группе составила 48\%, безрецидивная выживаемость (БРВ) - 60\%. Медиана наблюдения составила 3 года 7 мес. Пятилетняя ОВ в группе ОЛЛ была 46,2\%, в группе ОМЛ - 53,3\%, в группе МДС и МПЗ - 44,4\%. Причины летальности: рецидив/прогрессия в 17 случаях (65\%).Трансплантационная летальность составила 18\% (95\% ДИ, 8,8\%-29,8\%). Кумулятивная частота рецидива составила 34\% (95\% ДИ, 21,6\%-48\%).

\section{Заключение}

Повторная алло-ТГСК - эффективный метод терапии у пациентов с рецидивом заболевания после первой ТГСК. Пациенты, достигшие ремиссии или циторедукции перед алло-ТГСК, имеют статистически достоверный лучший прогноз. Развитие хронической РТПХ легкой и средней степени статистически улучшает ОВ. Не получено достоверной разницы между РИК и МАК. Посттрансплантационная терапия может улучшить результаты повторной алло-ТГСК.

\section{Ключевые слова}

Рецидив острого лейкоза, повторная алло-ТГСК, посттрансплантационная терапия, дети. 